\title{
Correction to: Microphysics and Optical Attenuation in Fog: Observations from Two Coastal Sites
}

Qing Wang ${ }^{1,3^{D}} \cdot$ Ryan T. Yamaguchi ${ }^{1} \cdot$ John A. Kalogiros ${ }^{2} \cdot$ Zachary Daniels $^{1}$. Denny P. Alappattu ${ }^{3}$. Haflidi Jonsson ${ }^{1}$. Oswaldo Alvarenga ${ }^{4}$. Alex Olson ${ }^{1}$. Benjamin J. Wauer ${ }^{1}$. David G. Ortiz-Suslow ${ }^{1} \cdot$ Harindra Joseph Fernando $^{5}$

Published online: 21 November 2021

(c) The Author(s) 2021

\section{Correction to: Boundary-Layer Meteorology https://doi.org/10.1007/s10546-021-00675-5}

In the original publication, the inset figure in Fig. 10b was missed mistakenly. The correct Fig. 10 is provided in this correction.

The original article has been corrected.

The original article can be found online at https://doi.org/10.1007/s10546-021-00675-5.

\section{Qing Wang}

qwang@nps.edu

1 Department of Meteorology, Naval Postgraduate School, Monterey, CA 93943, USA

2 National Observatory of Athens, Athens, Greece

3 Moss Landing Marine Laboratory, Moss Landing, CA 95039, USA

4 Naval Air Warfare Center Weapons Division, China Lake, CA 93555, USA

5 Civil and Environmental Eng. And Earth Sciences, University of Notre Dame, Notre Dame, IN 46556, USA 
(a)

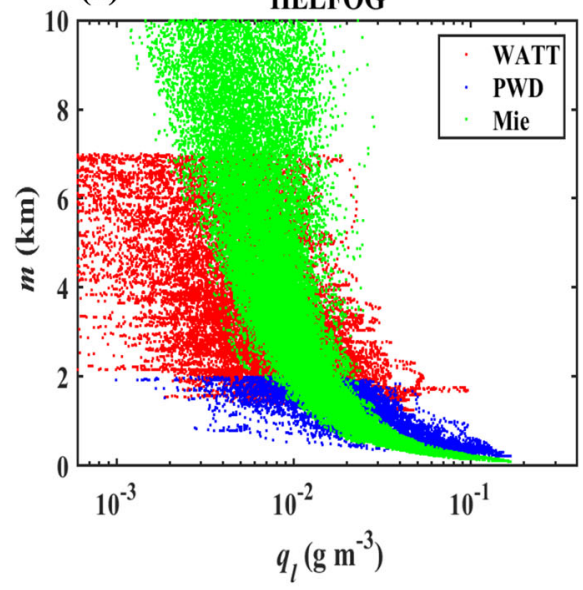

(b) C-FOG

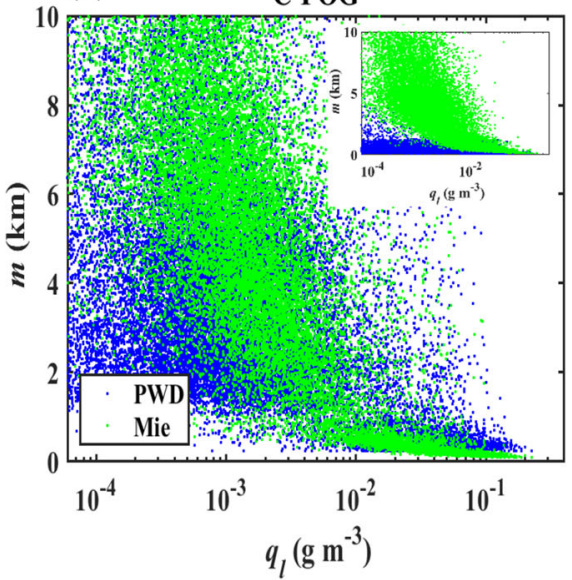

Fig. 10 Variation of visibility (MOR) with LWC $\left(q_{l}\right)$ from (a) HELFOG, and (b) C-FOG fog events. Results from the C6 event are shown in the inset. The blue dots are from the PWD sensors, red from WATT (HELFOG only) and all green dots are results from the Mie calculation. Data shown here are 1-min averages

Open Access This article is licensed under a Creative Commons Attribution 4.0 International License, which permits use, sharing, adaptation, distribution and reproduction in any medium or format, as long as you give appropriate credit to the original author(s) and the source, provide a link to the Creative Commons licence, and indicate if changes were made. The images or other third party material in this article are included in the article's Creative Commons licence, unless indicated otherwise in a credit line to the material. If material is not included in the article's Creative Commons licence and your intended use is not permitted by statutory regulation or exceeds the permitted use, you will need to obtain permission directly from the copyright holder. To view a copy of this licence, visit http://creativecommons.org/licenses/by/4.0/.

Publisher's Note Springer Nature remains neutral with regard to jurisdictional claims in published maps and institutional affiliations. 